\title{
Risk assessment for multiple myeloma: Preliminary results of The Brazilian Myeloma Study Group
}

\author{
Avaliação de risco em mioloma múltiplo: Resultados preliminares do Grupo Brasileiro de \\ Estudos de Mieloma
}

\author{
Angelo Maiolino* \\ Vania Hungria ${ }^{1}$ \\ Gislaine D. Oliveira ${ }^{2}$ \\ Eliana C. M. Miranda ${ }^{2}$ \\ Roberto Magalhães ${ }^{3}$ \\ Daniel Mercante \\ Eduardo M. Rego ${ }^{4}$ \\ Luciana Oliveira ${ }^{4}$ \\ Carlos S. Chiattone \\ Marcio Nucci ${ }^{3}$ \\ Irene Lorand-Metze $e^{2}$ \\ Ilana Zalcberg \\ Cármino A. de Souza
}

\begin{abstract}
The Durie/Salmon staging system continues to be used worldwide in patients with multiple myeloma. However, in recent years, new systems have been proposed. The International Myeloma Working Group performed a retrospective study with 11,179 patients and proposed an "International Staging System" utilizing serum levels of â2 microglobulin and albumin. In addition, current research has focused on the usefulness of cytogenetic and molecular data as prognostic factors. These data suggest that these parameters are powerful discriminators of a poor prognostic group of myeloma patients. Indeed, these prognostic indexes have been utilized in clinical trials, with interesting and encouraging results. Rev. bras. hematol. hemoter. 2008;30(Supl. 2):6-9.
\end{abstract}

Key words: Prognostic factors; multiple myeloma; molecular biology; treatment.

\section{Introduction}

Multiple myeloma (MM) is a malignant clonal plasma cell disorder accounting for $1 \%$ of all cancers and $10 \%$ of hematological malignancies. ${ }^{1}$ The main characteristic of the disease is the clonal proliferation of plasma cells, and the production, in the majority of cases, of a monoclonal heavy and/or light chain immunoglobulin (M-protein). ${ }^{2}$ This disease occurs in older population, with median age at presentation of 65 years. $^{3}$ Fewer than $2 \%$ of MM patients are under 40 years old at diagnosis. ${ }^{4}$ The survival of MM patients varies from a few months to more then ten years, depending on characteristics related to the disease itself (plasma cells abnormalities, tumor mass, stromal factors), as well as to host factors. ${ }^{5 ; 6}$ These risk factors for the development and progression of disease have been considered to be critical in the comparison of outcomes within and between different clinical trials. This strategy of assessing the patient according to the presence of risk factors is important on an individual basis, because it can predict the outcome. In addition, it adequately stratifies the patients in clinical studies..$^{7-10}$

Clinical, biological and molecular factors adversely influence the outcome, and prognostic models have been developed trying to stratify patient into groups of different survivals. ${ }^{5 ; 710-12}$

\section{Prognostic assessment}

The prognostic assessment has been based on risk factors, and can be divided in:

\footnotetext{
*Associate Professor of Medicine. Universidade Federal do Rio de Janeiro (UFRJ) - Rio de Janeiro-RJ.

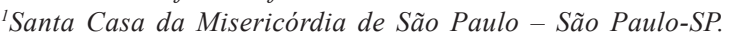

${ }^{2}$ Universidade Estadual de Campinas (Unicamp) - Campinas-SP.

${ }^{3}$ Universidade Federal do Rio de Janeiro (UFRJ) - Rio de Janeiro-RJ.

${ }^{4}$ Universidade de São Paulo (USP) - Ribeirão Preto-SP.

${ }^{5}$ Instituto Nacional de Câncer (Inca) - Rio de Janeiro-RJ.
}

Correspondence: Angelo Maiolino

Department of Internal Medicine - Universidade Federal do Rio de Janeiro - UFRJ

Hospital Universitário Clementino Fraga Filho

Av. Brigadeiro Trompovsky, s/ $n^{\circ}, 4^{\circ}$ andar, sala $4 A 12$ - Ilha do Fundão

21941-590 - Rio de Janeiro-RJ - Brazil

E-mail:maiolino@hucff.ufrj.br 
- Clinical factors:

1. age distribution: poorer survival in older patients;

2. performance status

- Factors related to the biology of the malignant clone:

1. cytogenetic and molecular abnormalities

2. proliferation index (high proliferative activity)

- Tumor mass and organ damages:

1. renal failure (creatinine)

2. high serum levels of $\beta 2$-microglobulin and $\mathrm{C}$-reactive protein

Since the development of the Durie/Salmon staging system 3 decades ago, new prognostic models that include these three groups of characteristics have been proposed. ${ }^{12}$ The Durie/Salmon staging system takes into account clinical and laboratorial parameters, trying to estimate the tumor mass, and consequently the prognosis. Analyzing the presence of four factors at diagnosis (anemia, M protein, calcium and lytic bone lesions) and presence of high serum creatinine levels, this system divided MM patients in three defined groups, with three different survival curves.

Looking for other prognostic markers, the level of $\beta 2$ microglobulin showed to be an interesting prognostic factor because it correlates with tumor mass and renal dysfunction. The cutoff of $6 \mathrm{mg} / \mathrm{L}$ of 32 microglobulin was able to divide MM patients in two groups of different prognoses..$^{13}$ In 2003, the International Myeloma Study Group suggested another staging system that incorporates the beta-2-microglobulin. This system is easier than the Durie/ Salmon, and still predicts the outcome. ${ }^{10}$ This staging system, called "International Staging System" (ISS), was based on only two variables ( $\beta 2$ microglobulin and albumin), and was able to define three prognostic groups with different median survivals.

Table 1. International Staging System (ISS)

\begin{tabular}{llc}
\hline Stage & Criteria & $\begin{array}{c}\text { Median survival } \\
\text { (months) }\end{array}$ \\
\hline I & Serum $\beta 2$ microglobulin $<3,5 \mathrm{mg} / \mathrm{L}$ and \\
& serum albumin $>35 \mathrm{~g} / \mathrm{L}$ & 62 \\
II & Neither I or III & 45 \\
III & Serum $\beta 2$ microglobulin $>5,5 \mathrm{mg} / \mathrm{L}$ & 29 \\
\hline
\end{tabular}

The comparison between these two staging systems showed that the ISS is better to define patients in stage I and II than Durie/ Salmon, and that patients in stage III of the ISS have worse prognosis than stage III of Durie/Salmon. ${ }^{10}$

The ISS has been validated on different settings of patients and treatments of MM, including a recent analysis among 1.112 Brazilians patients diagnosed during the past seven years. ${ }^{14}$
The $\mathrm{C}$-reative protein is another marker of tumor mass that has been used as prognostic factor. It has a good correlation with tumor growth, and it is independent of the $\beta 2$ microglobulin levels. Another index score that incorporates this marker is under study. ${ }^{15}$

Other factors that correlate with the outcome include plasma cell morphology, type of bone marrow infiltration, expression of adhesion molecules (CD56), high proliferative activity, and angiogenesis. ${ }^{16-20}$

Recently, various cytogenetic abnormalities present in the myeloma clonal cells were studied, and were strong prognostic factors. By conventional cytogenetic analysis, at least $39 \%$ of MM patients exhibit cariotypic abnormalities. ${ }^{21}$ With the use of tests with greater sensitivity, such as FISH analysis, several abnormalities have been described, in a greater proportion of patients..$^{22}$ Deletions/monosomy of chromosome 13, non-hyperdiploidy, and certain balanced translocations (including chromosome 14) are predictors of poor outcome..$^{23-25}$ The deletion or monosomy of chromosome 13 represents the most prevalent abnormality, accounting for $50 \%$ of the abnormalities observed. This abnormality occurs in $45 \%$ of patients with MM analyzed by molecular technique (FISH analysis). ${ }^{24 ; 26 ; 27}$ and its presence is independently associated with poorer survivals and duration of complete remission. ${ }^{21}$

With the addition of all these new molecular profiles to clinical variables, new staging systems may be even more powerful to identify prognostic groups.

Data presented recently by the Intergroupe Francophone du Myelome (IFM) showed a high incidence of cytogenetic abnormalities, in agreements with other studies, but they were able to identify three groups of patients with different median overall survivals, according to $\beta 2$ microglobulin levels and the presence of $t(4 ; 14)$ or $\operatorname{del}(17 p)$. The best overall survival was observed among patients with $\beta 2$ microglobulin levels $<3 \mathrm{mg} / \mathrm{L}$ and absence of $\mathrm{t}(4 ; 14)$ or del $(17 \mathrm{p})$. This profile was observed in $35 \%$ of patients. Patients with the worst overall survival (median 2 years) comprised $15 \%$ of patients, and included $\beta 2$ microglobulin $>3 \mathrm{mg} / \mathrm{L}$ and the presence of either $\mathrm{t}(4 ; 14)$ or del $(17 \mathrm{q})$. The other $50 \%$ of patients belonged to an intermediate group. ${ }^{26}$

\section{Clinical applicability}

The rational of staging a patient is to quickly identify high risk patients, and target the most appropriated therapy for each case. Unfortunately, this is not yet standard of care, but it is a matter of several clinical trials worldwide. ${ }^{7 ; 25 ; 27-30} \mathrm{~A}$ recent study of the IFM based the treatment of MM on the staging of the patients. It suggested dividing patients in two groups, according to $\beta 2$-microglobulin levels and the presence of chromosome 13 deletion. High risk patients were those with $\beta 2>3 \mathrm{mg} / \mathrm{L}$ and the presence of del 13 by FISH analysis. 
Patients without these high risk criteria were treated with two consecutive stem cell transplants conditioned with melphalan $140 \mathrm{mg} / \mathrm{m}^{2}$ and $200 \mathrm{mg} / \mathrm{m}^{2}$ (IFM 99-02). Patients classified as high risk were enrolled in treatment strategies that included higher doses of chemotherapy (200 and $220 \mathrm{mg} / \mathrm{m}^{2}$ of melphalan), followed by two autologous stem cell transplants (IFM 99-04) or one autologous and one HLA-identical sibling dose-reduced allogeneic transplant (IFM 99-03). The IFM 99-04 showed that in high-risk patients, the dose intensity of melphalan at $420 \mathrm{mg} / \mathrm{m}^{2}$ led to encouraging results, but the addition of anti-IL6 monoclonal antibody to the second conditioning regimen did not improve the outcome..$^{25}$ The IFM 99-02 showed that maintenance with thalidomide after the autologous transplant resulted in an improvement in the response rate, event free survival and overall survival in patients without deletion of chromosome 13 and / or in those with a beta- 2 microglobulin $<3,0 \mathrm{mg} / \mathrm{L} .^{28}$

Treatment based on risk assessment has been also proposed in a prospective studied by Brazilians researchers. The treatment protocol includes a stratification based on the presence of deletion of chromosome 13 and $\beta 2$ microglobulin $>2.5 \mathrm{mg} / \mathrm{L}$ (high risk). For patients without high risk criteria, an induction remission with chemotherapy (VAD) is followed by a single autologous peripheral blood transplant using melphalan $200 \mathrm{mg} / \mathrm{m}^{2}$. Patients are then randomized to receive maintenance treatment with dexamethasone with or without thalidomide $200 \mathrm{mg} /$ day. For high risk patients, the protocol consists of a first autologous transplant with melphalan $200 \mathrm{mg} / \mathrm{m}^{2}$, followed by a second transplant with the same conditioning regimen, or a dose-reduced allogeneic transplant if the patient has a matched donor. After the second transplant, patients are randomized to receive maintenance treatment with chemotherapy (DCEP) + / - thalidomide. From October 2003 to January 2008, 229 untreated patients under 70 years old were enrolled. The median observation time for whole group was 22 months and for alive patients 24 mo (1-62). 44 out $179(24 \%)$ died, most of them in VAD phase due to progression. 135/179 (76\%) are alive, ISS I 45/53 (85\%), ISS II $57 / 68(84 \%)$ and ISS III $33 / 58(57 \%)(\mathrm{p}<0.001)$. The OS in 60 mo by ISS was $76 \%, 75 \%$ and $36 \%$ for ISS I, II and III, respectively $(\mathrm{p}<0.0001)$. The EFS in 60 mo by ISS was $38 \%$, $32 \%$ and $10 \%$ for ISS I, II and III, respectively ( $<<0.0001$ ). The ANOVA showed significant difference for plasma cells bone marrow infiltration, creatinine and hemoglobin levels $(p<0.0001)$. The authors emphasized the importance of ISS at diagnosis due to high capacity to discriminate among groups with low cost. The protocol is still ongoing.

\section{Conclusions and recommendations}

Staging patients according to prognostic factors has been the subject of several researches and has been used to guide clinical trial protocols. In the future, this approach is hoped to help in defining treatment regimens on a patient basis, with a favorable impact on the prognosis.

The recommendation of recent guidelines on the management of MM (4) includes:

1. The International Prognostic Index based on serum albumin and $\beta 2$ microglobulin in preference of Durie/Salmon staging system.

2. Evaluate prognosis before starting treatment with, as a minimum, serum levels of $\beta 2$ microglobulin and albumin. Cytogenetic and/or FISH analysis may be helpful if available.

3. At present there is no evidence to support using prognostic factors to choose therapy in individual patients.

\section{Resumo}

O esquema de Durie / Salmon continua a ser utilizado para estadiar os pacientes com mieloma múltiplo. Recentemente, um novo sistema mais simples e eficaz foi proposto. O "International Myeloma Working Group" realizou um estudo retrospectivo com 11.179 pacientes e a partir destes dados propôs a criação de um "International Staging System (ISS)" utilizando os níveis séricos de $\beta 2$ microglobulina e de albumina ao diagnóstico. Além do ISS a pesquisa está voltada para identificar alterações citogenéticas e moleculares que se correlacionem com o prognóstico no mieloma múltiplo. Estes fatores prognósticos têm sido utilizados para estratificar pacientes em ensaios clínicos com resultados promissores. Rev. bras. hematol. hemoter. 2008;30(Supl. 2):6-9.

Palavras-chave: Fatores prognósticos; mieloma múltiplo; biologia molecular; tratamento.

\section{References}

1. Alexanian R, Haut A, Khan AU, et al. Treatment for multiple myeloma. Combination chemotherapy with different melphalan dose regimens. JAMA. 1969;208(9):1680-5.

2. Alexanian R, Barlogie B, Tucker S. VAD-based regimens as primary treatment for multiple myeloma. Am J Hematol. 1990; 33(2):86-9.

3. Pasqualetti P, Collacciani A, Colantonio D, Casale R. [Multiple myeloma: epidemiologic and clinical considerations]. G Ital Oncol. 1990;10(3):71-6.

4. Smith A, Wisloff F, Samson D. Guidelines on the diagnosis and management of multiple myeloma 2005. Br J Haematol. 2006; 132(4):410-51.

5. Paule B. [Prognostic factors of multiple myeloma]. Ann Med Interne (Paris). 1997;148(8):534-41.

6. San Miguel JF, Sanchez J, Gonzalez M. Prognostic factors and classification in multiple myeloma. Br J Cancer 1989;59(1): 113-8.

7. Durie BG, Bataille R. Therapeutic implications of myeloma staging. Eur J Haematol Suppl. 1989;51:111-6.

8. Durie BG, Kyle RA, Belch A et al. Myeloma management guidelines: a consensus report from the Scientific Advisors of the International Myeloma Foundation. Hematol J. 2003;4(6):379-98. 
9. Garban F, Attal M, Michallet M et al. Prospective comparison of autologous stem cell transplantation followed by a dose-reduced allograft (IFM99-03 trial) with tandem autologous stem cell transplantation (IFM99-04 trial) in high-risk de novo multiple myeloma. Blood. 2006;107(1):397-403.

10. Greipp PR, San MJ, Durie BG et al. International staging system for multiple myeloma. J Clin Oncol. 2005;23(15):3412-20.

11. Bataille R, Durie BG, Grenier J, Sany J. Prognostic factors and staging in multiple myeloma: a reappraisal. J Clin Oncol. 1986; $4(1): 80-7$.

12. Durie BG, Salmon SE. A clinical staging system for multiple myeloma. Correlation of measured myeloma cell mass with presenting clinical features, response to treatment, and survival. Cancer. 1975;36(3):842-54.

13. Bataille R, Grenier J, Sany J. Beta-2-microglobulin in myeloma: optimal use for staging, prognosis, and treatment--a prospective study of 160 patients. Blood. 1984; 63(2):468-76.

14. Hungria V, Maiolino A, Martinez G et al. Validation of the International Staging System (ISS) for multiple myeloma: a retrospective analysis of 487 patients at 8 Brazilian centers. Haematologica. 2008;93(5):791-2

15. Bataille R, Boccadoro M, Klein B, Durie B, Pileri A. C-reactive protein and beta-2 microglobulin produce a simple and powerful myeloma staging system. Blood. 1992;80(3):733-7.

16. Terpstra WE, Lokhorst HM, Blomjous F, Meuwissen OJ, Dekker AW. Comparison of plasma cell infiltration in bone marrow biopsies and aspirates in patients with multiple myeloma. Br J Haematol. 1992;82(1):46-9.

17. Rawstron A, Barrans S, Blythe D et al. Distribution of myeloma plasma cells in peripheral blood and bone marrow correlates with CD56 expression. Br J Haematol. 1999;104(1):138-43.

18. Rawstron AC, Owen RG, Davies FE et al. Circulating plasma cells in multiple myeloma: characterization and correlation with disease stage. Br J Haematol. 1997;97(1):46-55.

19. Ribas C, Colleoni GW, Silva MR, Carregoza MJ, Bordin JO. Prognostic significance of vascular endothelial growth factor immunoexpression in the context of adverse standard prognostic factors in multiple myeloma. Eur J Haematol. 2004; 73(5):311-7.

20. Ribas C, Colleoni GW, Felix RS et al. p16 gene methylation lacks correlation with angiogenesis and prognosis in multiple myeloma. Cancer Lett. 2005;222(2):247-54.

21. Tricot G, Barlogie B, Jagannath S et al. Poor prognosis in multiple myeloma is associated only with partial or complete deletions of chromosome 13 or abnormalities involving $11 \mathrm{q}$ and not with other karyotype abnormalities. Blood. 1995;86(11):4250-6.

22. Flactif M, Zandecki M, Lai JL et al. Interphase fluorescence in situ hybridization (FISH) as a powerful tool for the detection of aneuploidy in multiple myeloma. Leukemia. 1995;9(12): 2109-14.

23. Facon T, vet-Loiseau H, Guillerm G et al. Chromosome 13 abnormalities identified by FISH analysis and serum beta2microglobulin produce a powerful myeloma staging system for patients receiving high-dose therapy. Blood. 2001;97(6): 1566-71.

24. Braggio E, Magalhaes R, Maiolino A, Zalcberg I. Study of cromosomal abnormalities with prognostic impact in pacients with multiple myeloma. Revista Brasileira de Hematologia e Hemoterapia. 2005;27(4):162-3.

25. Moreau P, Hullin C, Garban F et al. Tandem autologous stem cell transplantation in high-risk de novo multiple myeloma: final results of the prospective and randomized IFM 99-04 protocol. Blood. 2006;107(1):397-403.
26. Loiseau H, Attal M, Moreau P et al. A comprehensive analysis of citogenetic abnormalities in Myeloma: results of the FISH analysis of 1000 patients enrolled in IFM99 trials. Blood (ASH Meeting Abstracts) 106, Abstract 622. 2005.

27. Maiolino A, Magalhaes R, Nucci M et al. Fase III, multicenter, prospective trial to treatment of early diagnosed multiple myeloma. Aprouch based on risk. Preliminary results. Rev. bras. hematol. hemoter. 2005;27(4)163.

28. Attal M, Harrousseau J, Leyvraz S et al. Maintanance therapy with thalidmide improves survival in patients with multiple myeloma. Blood. 2006;108(10):3289-94.

29. Barlogie B, Jr., Shaughnessy JD. Early results of total therapy II in multiple myeloma: implications of cytogenetics and FISH. Int J Hematol 2002;76 Suppl 1:337-339.

30. Riccardi A, Ucci G, Luoni R et al. Treatment of multiple myeloma according to the extension of the disease: a prospective, randomised study comparing a less with a more aggressive cystostatic policy. Cooperative Group of Study and Treatment of Multiple Myeloma. Br J Cancer. 1994;70(6):1203-10.

O tema apresentado constou do programa do Encontro AIBE. Avaliadores: Professores Ângelo Maiolino, Cármino Antonio de Souza e Marcio Nucci.

Publicado após concordância do editor.

Conflito de interesse: não declarado.

Recebido: 09/05/2008

Aceito: 20/05/2008 